\title{
ASSOCIAÇÃO DO AMÁLGAMA DE PRATA COM CIMENTO DE IONÔMERO DE VIDRO COMO MAIS UMA ALTERNATIVA RESTAURADORA EM ODONTOPEDIATRIA RELATO DE CASO CLÍNICO
}

Ana Alice Coelho TORRES, Francille Pereira CARNEIRO, Edo HIRATA

O amálgama de prata ainda é um material restaurador que tem sua aplicação na clínica odontológica infantil, devido às suas propriedades satisfatórias tais como, grande resistência ao desgaste, estabilidade, insolubilidade aos fluidos orais, relativo baixo custo, fácil manipulação e baixa sensibilidade técnica, além disso, quando exposto ao meio bucal sofre corrosão, e os produtos originados dessa corrosão, se depositam na interface dente-restauração, o que contribui na diminuição da infiltração marginal. Entretanto, a ausência de adesão à estrutura dentária, torna as restaurações de amálgama sujeitas a microinfiltração marginal, um dos principais fatores de lesões de cárie secundária. Este trabalho tem por objetivo apresentar uma técnica restauradora utilizada em odontopediatria, onde o amálgama de prata foi associado a um cimento de ionômero de vidro resinoso do tipo restaurador. Paciente do sexo masculino procurou a Clínica de Odontologia da Unioeste para tratamento odontológico. O mesmo foi submetido a anamnese, exame clínico e radiográfico. A partir dos dados obtidos foi realizado o plano de tratamento. Como o paciente apresentou atividade de doença cárie os materiais restauradores de escolha foram o amálgama e cimentos de ionômero de vidro. Através da associação de dois materiais restauradores pode-se melhorar a qualidade e longevidade das restaurações.

Palavras-chave: Amálgama dentário; cimentos de ionômeros de vidro; Odontopediatria. 